\title{
TOXICITY OF SOME INSECT GROWTH REGULATORS (IGRS) AND THEIR BINARY MIXTURES WITH OILS ON COTTON LEAFWORM LARVAE SPODOPTERA LITTORALIS (BOISD) \\ Hamed, S. A. \\ Plant Protection Dept.(Pesticides), Fac. of Agric., Tanta Univ., Egypt.
}

\section{ABSTRACT}

Toxicity effects of tow insect growth regulators (IGRs) chlorfluazuron and flufenoxuron alone and their combinations with oils at quarter, half and recommended rates were studied by using second $\left(2^{\text {nd }}\right)$ and fourth $4^{\text {th }}$ larval instars of the cotton leafworm, Spodoptera littoralis. (Boisduval). The results achieved in this study can be summarized in the following, chlorfluazuron was more toxic on both $2^{\text {nd }}$ and $4^{\text {th }}$ larval instars than flufenoxuron when used alone at quarter, half and recommended rates. Concerning the effect of binary mixtures of the tested compounds at half-and quarter recommended dose, chlorfluazuron when mixed with $\mathrm{Kz}$ oil exhibited highly mortalities against $2^{\text {nd }}$ nstar larvae of field strain of $S$. littoralis which caused $96.17 \%$ as residual effect compared with chlorfluazuron when used alone $(91.45 \%)$ at half recommended dose. While, chlorfluazuron + Hopa oil was recorded high mortality $94.47 \%$ at quarter- recommended dose as residual effect compared with chlorfluazuron when used alone (81.23\%) at the quarter recommended rate .Also, Flufenuxuron + Hopa oil has the highest residual activity $(95,25 \%)$ when compared to $79.10 \%$ for flufenuxuron alone at the half recommended rate. While, flufenuxuron + Misrona oil was recorded high mortality $82.93 \%$ as residual effect compared with $73.01 \%$ for flufenuxuron when used alone at the quarter recommended rate

Also, regarding the chlorfluazuron when mixed with $\mathrm{Kz}$ oil exhibited highly mortalities against $4^{\text {th }}$ instar larvae of field strain of $S$. littoralis which caused $95.40 \%$ as residual effect compared with chlorfluazuron when used alone (92.94\%) at the half recommended rate. While, chlorfluazuron $+\mathrm{Kz}$ oil was recorded high mortality $92.62 \%$ as residual effect as compared with chlorfluazuron when used alone $(80.48 \%)$ at the quarter recommended rate .The data also confirmed that, flufenuxuron + Hopa oil has the highest residual activity $(93,5 \%)$ when compared of $71.53 \%$ for flufenuxuron alone at the quarter recommended rate. While, flufenuxuron + Misrona oil was recorded high mortality $79.29 \%$ as residual effect compared with $70.96 \%$ for flufenuxuron when used alone at the quarter recommended rate .

It could be concluded that,the oils when mixed with IGRS enhanced the toxicity effect of IGRs against $2^{\text {nd }}$ and $4^{\text {th }}$ instar larvae of field strain of $S$ littoralis.

Keywords: IGRs, Oils, Spodoptera littoralis, cotton leafworm

\section{INRODUCTION}

The cotton leafworm Spodoptera littoralis (Boisduval). (Lepidoptrera : Noctuidae) is one of the most serious cotton pests in Egypt. Cotton leafworm S. littoralis considered most destructive pest attack all parts of cotton plants including green bolls. Chemical control is still adapted as one of the major techniques recommended to control such pest. The synthetic insecticides began to suffer from less potency controlling this pest owing to the increased rate developing resistance. The Egyptian cotton leafworm (S. littoralis) is an important and widespread pest of cultivated crops primarily in tropical and subtropical regions (Brown and Dewhurst, 1975). Because of its polyphagy, 
this species causes economical yield losses on several crops (Carter, 1984) .Considerable damage is recorded regularly on cotton, spinach, alfalfa, pepper, egg plant, tomato, lettuce, bean, strawberry and some ornamental crops. S. littoralis has been recorded throughout Africa, the Middle East, in the Mediterranean basin, Asia, and Europe (Bayoumi et al., 1998; El-Aswad et al., 2003; Pineda et al.,2007).In addition to the direct damage caused by reducing photosynthetic area, the occurrence of larvae, feeding damage and excrement reduce marketability of vegetables and ornamentals (Pluschkell et al., 1998). The intensive use of broad-spectrum insecticides against $S$. littoralis has led to the development of resistance to many registered pesticides use for its control (Smagghe et al., 1999 Aydin and Gürkan, 2006). Recently in Egypt, the use of conventional insecticide applications during the period when egg-masses predominate is not recommended to conserve natural enemy populations. Meanwhile the use of the insect growth regulators $\left(I_{G}\right)$ is considered as possible alternative for controlling the newly hatched larvae (Raslan, 2002). Insect growth regulators (IGRs) are compounds that can regulate the growth of insect pests and play an important role in integrated pest management systems (Kai et al., 2009). They are also called third-generation insecticides, as they disrupt the normal activity of the endocrine system of insects, affecting development, reproduction or metamorphosis of the target insects. IGRs include juvenile hormone (JH) mimics and chitin synthesis inhibitors (CSIs) (Hoffman and Lorenz, 1998; Tunaz and Uygun, 2004). IGR's considered new compounds, which kill the insect thought their interference with the mounting process, a process that is a vital to the well being of the insect (Moawad, 1974; Moawad et al., (1996). In addition to their larvicidal activity, they were effective in producing abnormalities in larval. pupa and adult stages of insects. Moreover,the effect extended to include reduction in number of eggs and percent hatchability. The present work aims to evaluate toxicity and latent effects of chlorfluazuron and flufenoxuron (IGR's) and their mixtures with different oils at the half, and quarter recommended rate against second $\left(2^{\text {nd }}\right)$ and fourth $\left(4^{\text {th }}\right)$ instar larvae of field strain of the cotton leafworm, S. littoralis (Boisd.).

\section{MATERIALS AND METHODS}

\section{Test insects:}

Cotton leafworm, Spodoptera littoralis (Boisd):Egg-masses of the cotton leafworm, S. littoralis (Boisduval): were collected early in the season from cotton field in Gemmeiza Agricultural Research Station Gharbia Governorate before the beginning of any chemical control programme and reared in the laboratory as described by El- Defrawi et al., (1964).

The tested compounds :

The insect growth regulator (IGRs) compound

- Chlorfluazuron (Atabron 5\%EC) 1-(3,5 dichloro - 4-(3- chloro-5trifluoromethyl-2-pyridyloxyl) phenyl)-3-(2,6 difluorobenzoyl) urea (Syngenta Company).

- Flufenuxuron (Cascade 10\%EC)1-(4-(2- chloro- $\alpha$, $\alpha$, $\alpha$ - trifluoro- $p$ tolyoxy2-fluorophenyl)-3- (2,6-difluoro benzoyl) urea. 


\section{Oils used}

- Hopa oil (plant oil). EC.69\% extracted from jojoba plant.

- Misrona oil $94 \%$ is a mineral oil, produced the Misr petroleum Co. Egypt.

- K.Z. oil (Mineral oil) (95\% E.C.) formulated mineral oil supplied by Kafer ElZayat pesticides and chemicals Company.

- Cottonseed oil, prepared as emulsifiable concentrate contained $93 \%$ base oil, used at concentration of $1.0-30.0 \%$.

- Natrilo ( $97 \%$ blend of vegetable oil, emulsifies and antioxidant).

Treatments:

\section{Experimental design:}

The cotton area was divided into plots, each plot $1 / 100$ of feddan , at Gemmeiza Agricultural Research Station Gharbia Governorate during 2011 season for assessing the toxicity of chlorfluazuron and flufenoxuron (IGR's) separately and their mixtures with different oils at quarter, half and recommended dose against second $\left(2^{\text {nd }}\right)$ and fourth $\left(4^{\text {th }}\right)$ instar larvae of field strain of the cotton leafworm, $S$. littoralis (Boisd.). Complete randomized blocks design was used and each treatment was replicated three times together with the control plots. The tested compounds and their binary mixtures were sprayed using a knapsack sprayer at their, quarter, half and recommended dose (200/ liters per feddan). All treatments are showan in Table (1).

Table (1): Teasted treatments, their rates of application, their binary mixtures and intervals of collecting post- treatment samples.

\begin{tabular}{|c|c|c|c|}
\hline No & Treatments & Rate / Feddan & $\begin{array}{l}\text { Intervals of teated cotton } \\
\text { leaves collected post- } \\
\text { treatment(days) }\end{array}$ \\
\hline 1 & $\begin{array}{l}\text { Chlorf. } \\
\text { Chlorf. } \\
\text { Chlorf. }\end{array}$ & $\begin{array}{l}400 . \mathrm{cm}^{3} \\
200 \mathrm{~cm}^{3} \\
100 \mathrm{~cm}^{3}\end{array}$ & 0. 3, 6, $9,12 /$ Rate \\
\hline 2 & $\begin{array}{l}\text { Chlorf.+ Natrilo } \\
\text { Chlorf.+ Natrilo }\end{array}$ & $\begin{array}{l}200 \mathrm{~cm}^{3}+1.5 \mathrm{~L} \\
100 \mathrm{~cm}^{3}+1,5 \mathrm{~L}\end{array}$ & $0.3,6,9,12 /$ Rate \\
\hline 3 & $\begin{array}{l}\text { Chlorf.+ Hopa oil } \\
\text { Chlorf.+ Hopa oil }\end{array}$ & $\begin{array}{l}200 \mathrm{~cm}^{3}+1.5 \mathrm{~L} \\
100 \mathrm{~cm}^{3}+1,5 \mathrm{~L}\end{array}$ & 0. 3, 6, $9,12 /$ Rate \\
\hline 4 & $\begin{array}{l}\text { Chlorf.+ Mesrona oil } \\
\text { Chlorf.+ Mesrona oil }\end{array}$ & $\begin{array}{l}200 \mathrm{~cm}^{3}+1.5 \mathrm{~L} \\
100 \mathrm{~cm}^{3}+1, \mathrm{~L}\end{array}$ & $0.3,6,9,12 /$ Rate \\
\hline 5 & $\begin{array}{l}\text { Chlorf.+ Kz oil } \\
\text { Chlorf.+ Kz oil }\end{array}$ & $\begin{array}{l}200 \mathrm{~cm}^{3}+1.5 \mathrm{~L} \\
100 \mathrm{~cm}^{3}+1,5 \mathrm{~L}\end{array}$ & 0. 3, 6, $9,12 /$ Rate \\
\hline 6 & $\begin{array}{l}\text { Chlorf.+ c.s.oil } \\
\text { Chlorf.+ c.s.oil }\end{array}$ & $\begin{array}{l}200 \mathrm{~cm}^{3}+1.5 \mathrm{~L} \\
100 \mathrm{~cm}^{3}+1,5 \mathrm{~L}\end{array}$ & $0.3,6,9,12 /$ Rate \\
\hline 7 & $\begin{array}{l}\text { Flu. } \\
\text { Flu. } \\
\text { Flu. }\end{array}$ & $\begin{array}{l}200 \mathrm{~cm}^{3} \\
100 \mathrm{~cm}^{3} \\
50 \mathrm{~cm}\end{array}$ & 0. $3,6,9,12 /$ Rate \\
\hline 8 & $\begin{array}{l}\text { Flu. + Natrilo } \\
\text { Flu. + Natrilo } \\
\end{array}$ & $\begin{array}{l}100 \mathrm{~cm}^{3}+1.51 \\
50 \mathrm{~cm}^{3}+1.5 \mathrm{~L}\end{array}$ & $0.3,6,9,12 /$ Rate \\
\hline 9 & $\begin{array}{l}\text { Flu. + Hopa oil } \\
\text { Flu. + Hopa oil }\end{array}$ & $\begin{array}{l}100 \mathrm{~cm}^{3}+1.51 \\
50 \mathrm{~cm}^{3}+1.5 \mathrm{~L}\end{array}$ & $0.3,6,9,12 /$ Rate \\
\hline 10 & $\begin{array}{l}\text { Flu.+ Mesrona oil } \\
\text { Flu.+ Mesrona oil }\end{array}$ & $\begin{array}{l}100 \mathrm{~cm}^{3}+1.51 \\
50 \mathrm{~cm}^{3}+1.5 \mathrm{~L}\end{array}$ & 0. 3, 6, $9,12 /$ Rate \\
\hline 11 & $\begin{array}{l}\text { Flu. }+ \text { Kz oil } \\
\text { Flu. }+ \text { Kz oil }\end{array}$ & $\begin{array}{l}100 \mathrm{~cm}^{3}+1.51 \\
50 \mathrm{~cm}^{3}+1.5 \mathrm{~L}\end{array}$ & $0.3,6,9,12 /$ Rate \\
\hline 12 & $\begin{array}{l}\text { Flu. + c.s.oil } \\
\text { Flu. + c.s. oil }\end{array}$ & $\begin{array}{l}100 \mathrm{~cm}^{3}+1.51 \\
50 \mathrm{~cm}^{3}+1.5 \mathrm{~L}\end{array}$ & $0.3,6,9,12 /$ Rate \\
\hline
\end{tabular}

Chlorf. = Chlorfluazuron, c.s. oil = cotton seed oil and Flu. = Flufenuxuron 
Hamed, S. A.

Samples of cotton leaves were collected at random from each treatment at intervals after spraying and the treated cotton leaves were offered to $2^{\text {nd }}$ and $4{ }^{\text {th }}$ instar larvae (50 larvae /treatment / interval). Larvae were fed on treated leaves during the two day of each interval and the survive larvae were fed for another three days on untreated leaves. Cumulative mortalities were calculated at the end of each interval and corrected according to Abbott's formula (1925). The cumulative mortalities of the first intervals samples collected after spraying directly was considered as initial kill, while the total mean of the cumulative mortalities of the other intervals were considered as residual effects. Data were statistically analyzed by the analysis of variance and significance were determined at $5 \%$ level of significant by Duncan Multiple range Test ( Snedecor 1962).

\section{RESULTS AND DISCUSSION}

Insect growth regulators (IGRs) are often considered as of lower impact on many beneficial organisms compared to other insecticides. They have attracted considerable attention recently for their inclusion in integrated pest management (IPM) programs, but effects are highly variable depending on the species and studied developmental stage Darvas and Polgar (1998) and Schneider, et al., (2003).IGRs are more effective on immature stages of insects compared to mature stages because they are known to disrupt the insect's normal processes of growth and development leading to eventual death. They have a slower knockdown rate resulting in extended time to kill pests. During insect development the shedding of the cuticle, known as molting, or ecdysis, occurs and all changes that involve growth, molting, and maturation are known as morphogenesis. The molting process begins when epidermal cells respond to hormonal changes by increasing their rate of protein synthesis. The first step of molting is a polysis: the separation of epidermal cells from the inner surface of the old endocuticle and the formation of the subcuticular space.

A molting gel (including enzymes) is secreted into this space. An insect larva that is actively constructing new exoskeleton is said to be in a pharate condition Marks (1980) and Truman et al., (1983). .

1-Toxicity of chlorfluazuron and flufenuxuron and in binary mixtures with different oils at quarter, half and recommended dose against 2 nd and $4^{\text {th }}$ instar larvae of field strain of $S$. littoralis.

Tables (2-5) represents the Initial effect at zero time and residual effect after 4 intervals (i.e.,3, 6, 9 and 12 days) from spraying of chlorfluazuron and flufenuxuron were applied alone and in binary mixtures with oils at quarter, half and recommended rates against $2^{\text {nd }}$ and $4{ }^{\text {th }}$ instar larvae of field strain of $S$ littoralis . Second and fourth instar larvae were fed on treated cotton leaves for 2 days, then alive larvae were fed on untreated cotton leaves for 3 days at each intervals. 
J. Plant Prot. and Path., Mansoura Univ., Vol. 3 (5), May, 2012

2 
Hamed, S. A.

3

458 
1.1. Effect of chlorfluazuron and flufenuxuron alone against $2^{\text {nd }}$ instar larvae of field strain of $S$ littoralis (Bosid) at quarter, half and recommended rate.

With regard to larval mortality, the data obtained in tables $(2,3)$ showed that, the chlorfluazuron when applied alone was more effective on $2^{\text {nd }}$ larval instar than flufenoxuron at the quarter, half- and recommended dose. Data revealed that, both IGRs has high initial and residual effects on the $2^{\text {nd }}$ larval instars which caused 100,100 ,and $100 \%$ as initial effect and, 81.23, 91.45 and $97 \%, 06$ mortality as residual effect at quarter, half, and recommended rate for chlorfluazuron respectively. While, initial and residual effects of flufenoxuron at quarter, half- and recomended dose were exhibited 100, 100 and $100 \%$ as initial effect and $73.01,79.10$ and $83.0 \%$ mortality as residual effect respectively.

It was noticed that, both IGRs resulted in $100 \%$ mortality after 5 days post treatment on the $2^{\text {nd }}$ instar. 5 days after treatment (initial activity), the effect of chlorfluazuron was similar to flufenoxuron which gave $100 \%$ mortality when applield alone.

The highest residual activity (period 3 and 12) of chlorfluazuron when used alone, was $97.07 \%$ at recommended dose compared with $83.0 \%$ for flufenoxuron on the $2^{\text {nd }}$ larval instars of the cotton leafworm, $S$. littoralis.

1.2. Effect of chlorfluazuron and flufenuxuron in binary mixtures with different oils against $2{ }^{\text {nd }}$ instar larvae of field strain of $S$. littoralis at quarter and half recommended dose.

Concerning the effect of binary mixtueres of the tested compounds at quarter half-, and recommended dose, chlorfluazuron when mixed with $\mathrm{Kz}$ oil exhibited highly mortalities against 2 nd instar larvae of field strain of $S$ littoralis which caused $96.17 \%$ as residual effect when compared with chlorfluazuron when used alone $(91.45 \%)$ followed by chlorfluazuron + cotton seed oil $91,99 \%$ at the half recommended rate. While, chlorfluazuron + Hopa oil was recorded high mortality $94.47 \%$ as residual effect table (2) compared with chlorfluazuron when used alone (81.23\%) at the quarter recommended rate.

Data presented in table (3) showed the initial and residual activities of the flufenuxuron when mixed with different oils against $2{ }^{\text {nd }}$ instar larvae of field strain of $S$. littoralis, flufenuxuron + Hopa oil has the highest residual activity $(95,25 \%)$ compared with $79.10 \%$ for flufenuxuron alone at half recommended rate. While, flufenuxuron + Misrona oil was recorded high mortality $82.93 \%$ as residual effect compared with $73.01 \%$ for flufenuxuron when used alone at the quarter recommended rate .

Results in Tables $(2,3)$ indicated generally that, $\mathrm{Kz}$ oil, Hopa oil and Misrona oil when combined with chlorfluazuron and flufenuxuron at half- and quarter recommended rate induced high mortality against $2{ }^{\text {nd }}$ instar larvae of field strain of $S$. littoralis

The comparative effectiveness of chlorfluazuron and flufenoxuron alone and in binaray mixtures at their recommended rates on the $2^{\text {nd }}$ larval instars of the cotton leafworm, $S$. littoralis, data showed that the chlorfluazuron was more effective than flufenuxuron at quarter and half recommended rate. 
It was noticed that, the highest residual activity of all tested mixtures with different oil ranged between $96,17 \%$ and $94.47 \%$ mortality on $2^{\text {nd }}$ larval instar by chlorfluazuron ,while $95.25 \%$ and $82.93 \%$ mortality by flufenoxuron at quarter and half recommended dose respectively.

\subsection{Effect of chlorfluazuron and flufenuxuron alone against $4^{\text {th }}$ instar larvae of field strain of $S$. littoralis (Bosid) at quarter, half and recommended dose.}

Concerning the larval mortality, data obtained in tables $(4,5)$ showed that the chlorfluazuron when applied alone was more effective on $4^{\text {th }}$ instar larvae than flufenoxuron at quarter, half- and recommended dose. Data revealed that, both IGRs has high initial and residual effects on $4^{\text {th }}$ instar larvae which caused 100,100 ,and $100 \%$ as initial effect and, 80.48, 92.94 and $97,07 \%$ mortality as residual effect at quarter, half-, and recommended rate for chlorfluazuron, respectively. While, initial and residual effects of flufenoxuron at quarter, half- and recomended dose were exhibited 100, 100,and 100\% and $70.96 .0 \%, 71.53$. \% and $83.25 \%$ respectively . It was noticed that, both IGRs resulted in $100 \%$ mortality after 5 days post treatment on $4^{\text {th }}$ instar larvae. 5 days after treatment (initial activity), the effect of chlorfluazuron was similar to flufenoxuron which gave $100 \%$ mortality when applield alone.

The highest residual activity (period 3 and 12) of chlorfluazuron when used alone was $97.07 \%$ at recommended dose compared with $83.25 \%$ for flufenoxuron on $4^{\text {th }}$ instar larvae of the cotton leafworm, $S$. littoralis.

1.4. Effect of chlorfluazuron and flufenuxuron in binary mixtures with different oils against $4^{\text {th }}$ instar larvae of field strain of $S$ littoralis (Bosid) at quarter and half recommended dose.

With respect to the effect of binary mixtueres of the tested compounds at quarter and half recommended rate, chlorfluazuron when mixed with $\mathrm{Kz}$ oil exhibited highly mortalities against $4^{\text {th }}$ instar larvae of field strain of $S$. littoralis which caused $95.40 \%$ as residual effect compared with chlorfluazuron when used alone $(92.94 \%)$ at the half recommended rate. While, chlorfluazuron $+\mathrm{Kz}$ oil was recorded high motality $92.62 \%$ as residual effect table (4) compared with chlorfluazuron when used alone $(80.48 \%)$ at the quarter recommended rate.

Data presented in Table (5) showed the initial and residual activities of flufenuxuron when mixed with different oils against $4^{\text {th }}$ instar larvae of field strain of S. littoralis. Fufenuxuron + Hopa oil has the highest residual activity $(93,5 \%)$ compared to $71.53 \%$ for flufenuxuron alone at half recommended rate. While, flufenuxuron + Misrona oil was recorded high mortality $79.29 \%$ as residual effect compared with $70.96 \%$ for flufenuxuron when used alone at the quarter recommended rate.

Results in Tables $(4,5)$ indicated generally that, Kz oil and Misrona oil when combined with chlorfluazuron and flufenuxuron at quarter and halfrecommended rate induced high mortality against $4^{\text {th }}$ instar larvae of field strain of $S$ littoralis

The comparative effectiveness of chlorfluazuron and flufenoxuron alone and in binaray mixtures at their recommended rates, on $4^{\text {th }}$ instar larvae of the cotton leafworm, $S$. littoralis, data showed that the chlorfluazuron was more effective than flufenuxuron at half and quarter recommended rate. 
J. Plant Prot. and Path., Mansoura Univ., Vol. 3 (5), May, 2012

4 
Hamed, S. A.

5

462 
It was noticed that, the highest residual activity of all tested mixtures with different oil ranged beteen $96,17 \%$ and $94.47 \%$ mortality on $2^{\text {nd }}$ larval instar by chlorfluazuron ,while $95.25 \%$ and $82.93 \%$ mortality by flufenoxuron at quarter and half recommended dose.

This data agrees with that of Abdel Rahman et al., (2007) when they tested the direct and latent effects of lufenuron and a lufenuron +deltant mixture on the development of $S$. littoralis larvae. Their findings showed that lufenuron has more toxic and delayed effects on tested larval instars.

Salokhe et al. (2006) found that sublethal concentrations of flufenoxuron caused significant reduction in the chitin content in the larvae of Tribolium castaneum on the $15^{\text {th }}$ day of development.They added that, sublethal concentrations of flufenoxuron on certain biochemical parameters in the larvae of $T$. castaneum which showed significant reduction in chitin content with all concentrations tested.

Toxicity effects and field persistence of the insect growth regulators, lufenuron, flufenoxuron and triflumuron were assessed by El-Sayed et al., (2011) in the laboratory using second and fourth larval instars of Spodoptera littoralis. Laboratory bioassays indicated that lufenuron was more effective on both $2^{\text {nd }}$ and $4^{\text {th }}$ larval instars, as well as killing both larval instars faster than flufenoxuron or triflumuron.

The efficiency of chlorfluazuron, teflubenzuron and flufenoxuron against third and fifth instars of both susceptible and field strains of $S$. littoralis, were investigated by Bayoumi et al. (1998) under laboratory conditions. They showed that third instars are more sensitive to the compounds tested than fifth instars.

Nasr et al. (2010) studed the lethal and sublethal effects of two insect growth regulators (IGRs), buprofezin and pyriproxyfen on activity of chitinase and polyphenol oxidase (PPO) were evaluated on larvae of cotton leafworm $S$. littoralis, the overall mortalities within 6 days of feeding at 2.0 -fold were $46.67 \%$ and $100 \%$ for buprofezin and pyriproxyfen, respectively.

In conclusion, IGRs are claimed to be safe or have little impact on beneficial organisms compared with conventional insecticides, and they have attracted considerable attention for their inclusion in IPM programs (Schoonover and Larson,1995; Darvas and Polgar,1998; Ishaaya and Horowitz, 1999;Walter, 1999; and Schneider et al., 2003). Because IGRs are extensively available nowadays, they are being tested in many ways including for their efficacy on many different insect pests (Perez-Farinos et al., 1998; Schneider et al., 2004; Salokhe et al., 2006; Ahire et al., 2008; Arnold et al., 2009; Kai et al., 2009;Tassou and Schulz, 2009; and Mansur et al., 2010) or in combination with entomopathogenic nematodes and fungi (Irigaray et al., 2003; Negrisoli et al., 2010a; b), as well as the development of insect resistance to their action (Ahmad et al., 2008).

Generally, it cauld be concluded that the use of insect growth regulator (IGRs) and their mixtures with different oils instead of conventional hazardous insecticides:were efficient as controlling for pests and this may reduce the environmental pollution and hazard effects on human health. Our data supported that IGRs are effective when applied in very minute quantities and apparently have no undesirable effects on human and wildlife. 
Consequently, when used with precision, IGRs may play an important role in insect pest management programs especially when mixed with mineral oils. In conclusion, the comparative effects of chlorflurazuron and, flufenoxuronon on the $2^{\text {nd }}$ and $4^{\text {th }}$ larval instar of $S$. littoralis after zero, 3,,6,9 and 12 days indicated that, chlorflurazuron was potential to kill $S$. littoralis larvae more efficiently than flufenoxuron.

\section{REFERENCES}

Abbott, W.S., (1925). A method of computing the effectiveness of an insecticide.J. Econ. Entomol. 18, 265-267.

Abdel Rahman, S.M., Hegazy, and E.M., Elwey, A.E., (2007). Direct and latent effects of two chitin synthesis inhibitors to Spodoptera littoralis larvae (Boisd). American- Eurasian J. Agric. Environ. Sci. 2 (4), 457464

Ahire, K.C., Arora, M.S., and Mukherjee, S.N., (2008). Development and application of a method for analysis of lufenuron in wheat flour by gas chromatographye massspectrometry and confirmation of bio-efficacy against Tribolium castaneum (Herbst) (Coleoptera: Tenebrionidae). J. Chromatogr. B. 861, $16 \mathrm{e} 21$.

Ahmad, M., Sayyed, A.H., Saleem, and M.A., Ahmad, M., (2008). Evidence for field evolved resistance to newer insecticides in Spodoptera lituralis (Lepidoptera: Noctuidae) from Pakistan

Arnold, K.E., Wells, C., and Spicer, J.I., (2009). Effect of an insect juvenile hormone analogue, Fenoxycarb on development and oxygen uptake by larval lobsters Homarus gammarus (L.). Comp. Bioch. Physiol. Part C $149,393 \mathrm{e} 396$.

Aydin, M.H., and Gürkan, M.O., (2006) The efficacy of spinosad on different strains of Spodoptera littoralis (Boisduval) (Lepidoptera: Noctuidae). Turk J. Biol. 30, 5- 9.

Bayoumi, A.E., Balaña-Fouce, R., Sobeiha, A.K., and Hussein, E.M.K., (1998). The biological activity of some chitin synthesis inhibitors against the cotton leafworm Spodoptera littoralis (Boisduval), (Lepidoptera: Noctuidae). Boletín de Sanidad Vegetal, Plagas Vol. 24 (No. 3), 499506. 21 ref.

Brown, E.S., Dewhurst, C.F.,( 1975). The genus Spodoptera in Africa and the near east. Bull. Entomol. Res. 65, 221-262.

Carter, D., (1984). Pest Lepidoptera of Europe with Special Reference to the British Isles. Junk Publishers, Dordrecht, The Netherlands.

Darvas, B., and Polgar, L.A., (1998). Novel type insecticides: specificity and effects on nontarget organisms. In: Ishaaya, I., Degheele, D. (Eds.), Insecticides with Novel Modes of Action. Springer, Berlin, pp. 188-259.

El-Aswad, A.F., Abdelgaleil, S.A.M., and Nakatani, M., (2003). Feeding deterrent and growth inhibitory properties of limonoids from Khaya senegalensis against the cotton leafworm, Spodoptera littoralis. Pest Manag. Sci. 60, 199-203. 
El-Defrawi, M.E.; A. Toppozade; N. Mansour and Zeid (1964). Toxicological studies on the Egyptian cotton leafworm; prodenia litura:I. Susuceptibity of different larval instar of prodenia to insecticides.J. Econ.Ent., $57:$ 591-593.

El-Sayed A. El-Sheikh, and Mohamed M. Aamir., (2011) Comparative effectiveness and field persistence of insect growth regulatorson a field strain of the cotton leafworm, Spodoptera littoralis, Boisd (Lepidoptera: Noctuidae Crop Protection 30 (2011) 645-650

Hoffman, K.H., and Lorenz, M.W., (1998). Recent advances in hormones in insect pest control. Phytoparasitica 26 (4), 1-8.

Irigaray, F.J.S.-C., Marco-Mancebón, V., and Pérez-Moreno, I., (2003). The entomopathogenic fungus Beauveria bassiana and its compatibility with triflumuron: effects on the two spotted spider mite Tetranychus urticae. Biol. Control 26, 168-173.

Ishaaya, I., and Horowitz, A.R., (1999). Insecticides with novel modes of action: an overview. In: Ishaaya, I., Degheele, D. (Eds.), Insecticides with Novel Modes of Action. Springer, Berlin, Germany, pp. 1-24

Kai, Z.-P., Huang, J., Tobe, S.S., and Yang, X.I, (2009). A potential insect growth regulator: synthesis and bioactivity of an allatostatin mimic. Peptides 30, 1249-1253.

Mansur, J.F., Figueira-Mansur, J., Santos, A.S., Santos-Junior, H., Ramos, I.B., Medeiros, M.N., Machado, E.A., Kaiser, C.RMuthukrishnan, S., Masuda, H.,Vasconcellos, A.M.H., Melo, A.C.A., and Moreira, M.F., 2010. The effect of lufenuron, a chitin synthesis inhibitor, on oogenesis Rhodnius prolixus. Pestic. Biochem. Physiol. 98, 59-67.

Marks, E.P. (1980). Insect tissue culture: an overview, 1971-1978, Ann. Rev. Entomol. 25 73-101.

Moawad, G.M. (1974). Effect of certain species of bollwonns Pectinophora gosvypiella (Saunders) and Earias insulana (Boisd) on cotton plants and yield in relation toagniculture oractices. Ph.D.Thesis, FAc. Of Agric., El-Azhar Univ.

Moawad, G.M:I.E.M.Salem:W.M.H.Desuky:A.A El-Sheakh and S.A.A.Raslan (1996). Latent effect of IGRs on egg-masses of Spodoptera littoralis (Bosid) treated with three IGRs in Egypt.Egyptan J.Agric.Res., 74(1): 115-121.

Nasr H. M., Mohamed E.I. Badawy, , Entsar I. and Rabea .,(2010) Toxicity and biochemical study of two insect growth regulators, buprofezin and pyriproxyfen, on cotton leafworm Spodoptera littoralis Pesticide Biochemistry and Physiology 98 (2010) 198-205

Negrisoli, A.S., Garcia, M.S., Negrisoli, C.R.C.B., Bernardi, D., and Silva, A., 2010a. Efficacy of entomopathogenic nematodes (Nematoda: Rhabditida) and insecticide mixtures to control Spodoptera frugiperda (Smith, 1797) (Lepidoptera: Noctuidae) in corn crops. Crop Prot. 29, 677-68 
Negrisoli Jr., A.S., Garcia, M.S.,and Negrisoli, C.R.C.B., 2010b. Compatibility of entomopathogenic nematodes (Nematoda: Rhabditida) with registered insecticides for Spodoptera frugiperda (Smith, 1797) (Lepidoptera: Noctuidae) under laboratory conditions. Crop Prot. 29, 545e549.

Perez-Farinos, G., Smagghe, G., Marco, V., Tirry, L., and Castanera, P., (1998). Effects of Topical application of hexaflumuron on adult Sugar Beet Weevil, Aubeonymus mariaefranciscae, on Embryonic development: Pharmacokinetics in adults and Embryos. Pestic. Biochem. Physiol. 61, 169-182

Pineda, S., Chneider, M.S., Smagghe, G., Marti'nez, A., Stal, P.D., Vinuela, E., Valle, J., and Budia, F., (2007). Lethal and sublethal effects of Methoxyfenozide and spinosad on Spodoptera littoralis (Lepidoptera: Noctuidae). J. Econ. Entomol. 100,773e780.

Pluschkell, U., Horowitz, A.R., Weintraub, P.G., and Ishaaya, I., (1998). DPXMP062- a potent compound for controlling the Egyptian cotton leafworm Spodoptera littoralis (Boisd.). Pestic. Sci. 54, 85e90.

Raslan, S.A.A., (2002). Preliminary Report on Initial and Residual Mortality of the Natural Product, Spinosad for Controlling Cotton Leaf Worm Egg Masses in 2002 Cotton Season at Sharkia Governorate; Egypt. 2nd International Conference. Plant Protection Research Institute, Cairo, Egypt. 21-24 December, 2002. Volume 1, 635-637.

Salokhe, S., Sarkar, A., Kulkarni, A., Mukherjee, S., and Pal, J.K., (2006). Flufenoxuron, an acylurea insect growth regulator, alters development of Tribolium castaneum (Herbst) (Coleoptera: Tenebrionidae) by modulating levels of chitin, soluble protein content, and HSP70 and p34cdc2 in the larval tissues. Pestic. Biochem. Physiol. 85, 84-90.

Schneider, M.I., Smagghe, G., Pineda, S., and Viñuelaa, E., (2004). Action of insect growth regulator insecticides and spinosad on life history parameters and absorption in third-instar larvae of the endoparasitoid Hyposoter didymator. Biol. Control 31,189-198.

Schneider, M, Smagghe, G and Viuela, E. (2003). Susceptibility of Hyposoter didymator (Hymenoptera: Ichenumonidae) adults to several IGRs pesticides and spinosad by different exposure methods, IOBC/wprs Bull. 26 111-122.

Schoonover, J.R., and Larson, L.L., (1995). Laboratory activity of spinosad on non-target beneficial arthropods. Arthropod Manage. Test. 20, 357.

Smagghe, G., Carton, B., Wesemael, W., Ishaaya, I., and Tirry, L., (1999). Ecdysone agonistsmechanismof action and applicationon Spodoptera species. Pestic. Sci. 55, 343-389.

Snedecor, G.W (1962). Statistical methods applied to experiments in Agricultural and Biology. The lowa State Univ.Press, Ames lowa, USA, $1523 p$.

Tassou, K.T., and Schulz, R., (2009). Effects of the insect growth regulator pyriproxyfen in a two-generation test with Chironomus riparius. Ecotoxicol. Environ. Safety. 72, 1058-1062. 
Truman, J.W, Rountree, D.B. Reiss, S.E and Schwartz, L.M. (1983) Ecdysteroids regulate the release and action of eclosion hormone in the tobacco hornworm, Manduca sexta (L.), J. Insect Physiol. 29 895900.

Tunaz, H., and Uygun, N., (2004). Insect growth regulators for insect pest control. J. Agric. Turk 28, 337-387.

Walter, J.F., (1999). Commercial experience with neem products. In: Hall, F.R.,Menn, J.J. (Eds.), Biopesticides: Use and Delivery. Humana, Totowa, NJ, pp.155e170

$$
\begin{aligned}
& \text { سمية بعض منظمات النمو الحشرية ومخاليطها مع الزيوت ضد الظور اليرقى الثانى } \\
& \text { والرابع لدودة ورق القطن }
\end{aligned}
$$

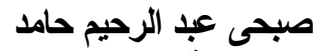

$$
\begin{aligned}
& \text { قسم وقاية النبات ( المبيدات)- كلية الزراعة - جامعة طنطا - جمهورية مصر العربية }
\end{aligned}
$$

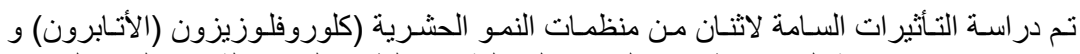

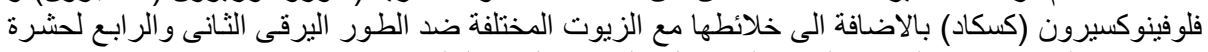

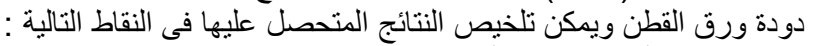

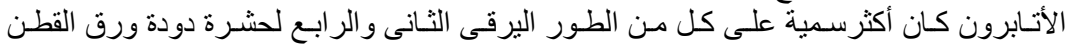

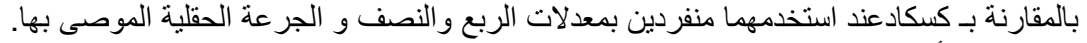

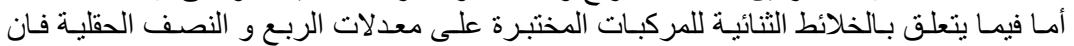

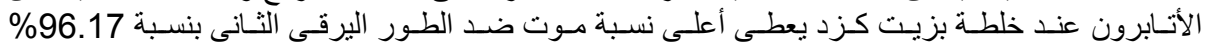

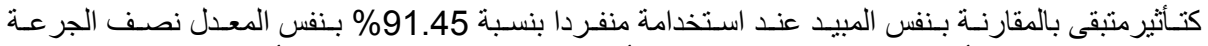

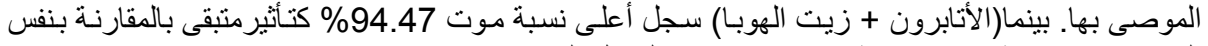

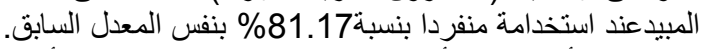

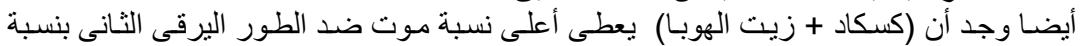

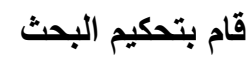

$$
\begin{aligned}
& \text { أ.د / على على على عبد الهادى البـ على } \\
& \text { أ.د / عطية قريط على أل عل }
\end{aligned}
$$


Hamed, S. A. 
J. Plant Prot. and Path., Mansoura Univ., Vol. 3 (5), May, 2012 
Hamed, S. A. 
J. Plant Prot. and Path., Mansoura Univ., Vol. 3 (5): 453 - 467, 2012 
Table (2): The initial and residual activity of quarter, half and recommended dose of Chlorfluazuron and their binary mixtures with oils against 2nd instar larvae of cotton leafworm S. littoralis

\begin{tabular}{|c|c|c|c|c|c|c|c|c|c|c|c|c|c|}
\hline \multirow[b]{3}{*}{ Treatments } & \multirow[b]{3}{*}{ Rate / fed } & \multicolumn{10}{|c|}{ Corrected $\%$ mortality at indicated time intervales } & \multirow{2}{*}{\multicolumn{2}{|c|}{$\%$ effectiveness }} \\
\hline & & \multicolumn{2}{|c|}{0 day } & \multicolumn{2}{|c|}{3 day } & \multicolumn{2}{|c|}{6 day } & \multicolumn{2}{|c|}{9 day } & \multicolumn{2}{|c|}{12 day } & & \\
\hline & & 2day & 5day & 2day & 5day & 2day & 5day & 2day & 5day & 2day & 5day & $\begin{array}{c}\text { Initial } \\
\text { activity } \\
\text { 2day }\end{array}$ & $\begin{array}{c}\text { Residual } \\
\text { activity } \\
\text { 5day }\end{array}$ \\
\hline Chlorfluazuron & $400 \mathrm{~cm}^{3}$ & $90 \mathrm{ab}$ & $100 \mathrm{a}$ & 80.12 & 100 & 95.8 & 100 & 69 & 97.81 & 30.12 & 90.44 & $68.76 \mathrm{a}$ & $97.06 \mathrm{a}$ \\
\hline Chlorfluazuron & $200 \mathrm{~cm}^{3}$ & $62 f$ & $100 \mathrm{a}$ & 71.15 & 100 & 92.4 & 100 & 39 & 95.61 & 24.14 & 70.2 & $56.68 \mathrm{ab}$ & $91.45 \mathrm{a}$ \\
\hline Chlorfluazuron & $100 \mathrm{~cm}^{3}$ & $70 a b c$ & $100 \mathrm{a}$ & 72.30 & 100 & 90.2 & 100 & 34 & 94.33 & 5.0 & 30.61 & $50.38 \mathrm{abc}$ & $81.23 a$ \\
\hline Chlorfluazuron + Natrilo & $\begin{array}{l}200 \mathrm{~cm}^{3}+ \\
1,5 \mathrm{~L}\end{array}$ & $94 a$ & $100 a$ & 69.33 & 100 & 84.82 & 100 & 39 & 96.66 & 40.60 & 85.33 & $58.34 \mathrm{bcd}$ & $88.75 a$ \\
\hline Chlorfluazuron + Natrilo & $\begin{array}{l}100 \mathrm{~cm}^{3}+ \\
1,5 \mathrm{~L}\end{array}$ & $72 a b c$ & $100 a$ & 60.4 & 100 & 83.51 & 100 & 29 & 88.67 & 16.60 & 50.11 & $47.63 \mathrm{~cd}$ & $84.70 a b$ \\
\hline $\begin{array}{l}\text { Chlorfluazuron + Hope } \\
\text { oil }\end{array}$ & $200 \mathrm{~cm}^{3}+$ & $89 a$ & $100 a$ & 81.12 & 100 & 84.81 & 100 & 39 & 95.56 & 31.12 & 59.90 & $59.01 \mathrm{bcd}$ & $88.78 a b$ \\
\hline Chlorfluazuron+ Hopa oi & ii $\begin{array}{ll}100 & \mathrm{~cm}^{3}+ \\
1,5 \mathrm{~L} & +\end{array}$ & $85 a$ & $100 a$ & 80.20 & 100 & 69.34 & 100 & 13 & 87.71 & 7.60 & 90.10 & 42.54abcd & $94.47 a$ \\
\hline \begin{tabular}{|l|} 
Chlorfluazuron \\
Mesrona oil \\
\end{tabular} & $+\begin{array}{ll}200 \mathrm{~cm}^{3} \\
1,5 \mathrm{~L}\end{array}$ & $81 a b$ & $100 \mathrm{a}$ & 88.20 & 100 & 78.22 & 100 & 48 & 90.61 & 14.71 & 60.51 & $57.33 a b$ & $87.78 \mathrm{ab}$ \\
\hline $\begin{array}{l}\text { Chlorfluazuron+ } \\
\text { Mesrona oil }\end{array}$ & $\begin{array}{l}100 \mathrm{~cm}^{3}+ \\
1,5 \mathrm{~L}\end{array}$ & $80 a b c$ & $100 a$ & 76.33 & 100 & 66.31 & 100 & 34 & 82 & 7.14 & 80.95 & $45.9 b c d$ & $90.74 a$ \\
\hline Chlorfluazuron + Kz oil & $\begin{array}{l}200 \mathrm{~cm}^{3}+ \\
1,5 \mathrm{~L}\end{array}$ & $79 a b c$ & $100 a$ & 75.57 & 100 & 56.24 & 100 & 40 & 92.17 & 30 & 92.50 & $50.45 a b c$ & $96.17 a$ \\
\hline Chlorfluazuron+ Kz oil & $\begin{array}{ll}100 \mathrm{~cm}^{3}+ \\
1,5 \mathrm{~L}\end{array}$ & 50def & $100 a$ & 60.66 & 100 & 50.33 & 100 & 26 & 83 & 14.20 & 93.50 & 37.81abcd & $94.13 a$ \\
\hline $\begin{array}{l}\text { Chlorfluazuron + cottor } \\
\text { seed oil }\end{array}$ & $\mathrm{n} 200 \mathrm{~cm}^{3}+$ & $72 a b c$ & $100 a$ & 70.4 & 100 & 44.63 & 99.04 & 41 & 93.13 & 17.62 & 75.82 & $43.41 d$ & $91.99 a$ \\
\hline $\begin{array}{l}\text { Chlorfluazuron+ cottor } \\
\text { seed oil }\end{array}$ & $\mathrm{n} \mid \begin{array}{ll}100 & \mathrm{~cm}^{3}+ \\
1,5 \mathrm{~L} & +\end{array}$ & $42 g$ & $100 a$ & 52.91 & 100 & 39.15 & 100 & 28 & 71.62 & 18.67 & 60.16 & $34.68 \mathrm{~cd}$ & 82.95ab \\
\hline
\end{tabular}

seed oil , $5 \mathrm{~L}$

Mean followed by the same letter in each column are not significantly at $5 \%$ level 
Table (3) : The initial and residual activity of quarter ,half and recommended dose of Flufenuxuron and their binary mixtures with oils against 2nd instar larvae of cotton leafworm S. littoralis

\begin{tabular}{|c|c|c|c|c|c|c|c|c|c|c|c|c|c|}
\hline \multirow[b]{3}{*}{ Treatments } & \multirow[b]{3}{*}{ Rate / fed } & \multicolumn{10}{|c|}{ Corrected $\%$ mortality at indicated time intervales } & \multirow{2}{*}{\multicolumn{2}{|c|}{$\%$ effectiveness }} \\
\hline & & \multicolumn{2}{|c|}{0 day } & \multicolumn{2}{|c|}{3 day } & \multicolumn{2}{|c|}{6 day } & \multicolumn{2}{|c|}{9 day } & \multicolumn{2}{|c|}{12 day } & & \\
\hline & & 2day & 5day & 2day & 5day & 2day & 5 day & 2day & 5day & 2day & 5day & $\begin{array}{l}\text { Initial } \\
\text { activity } \\
\text { 2day }\end{array}$ & \begin{tabular}{|l} 
Residual \\
activity \\
5day
\end{tabular} \\
\hline Flufenuxuron & $200 \mathrm{~cm}^{\circ}$ & $61 \mathrm{a}$ & $100 a$ & 73 & 100 & 86.71 & 100 & 25.91 & 70 & 20.91 & 62 & $51.63 a b c$ & $83.03 a b$ \\
\hline Flufenuxuron & $100 \mathrm{~cm}^{5}$ & $55 a b c$ & $100 a$ & 71 & 100 & 82.23 & 92.41 & 23.83 & 64 & 19.41 & 60 & $49.14 a b c d$ & $79.10 \mathrm{ab}$ \\
\hline Flufenuxuron & $50 \mathrm{~cm}^{3}$ & $53 a b$ & $100 a$ & 62 & 90.22 & $80 . .91$ & 90.22 & 19.42 & 60 & 11.21 & 54 & 43.39abcd & $73.61 \mathrm{bc}$ \\
\hline $\begin{array}{l}\text { Chlorfluazuron } \\
\text { Natrilo }\end{array}$ & $100 \mathrm{~cm}^{3}+1,5$ & $61 a b c$ & $100 a$ & 71 & 100 & 90.11 & 90.22 & 40.42 & 83 & 44.33 & $\begin{array}{l}54 \\
76\end{array}$ & $\begin{array}{l}\text { 43.09aded } \\
61.49 a b c\end{array}$ & $88.10 a b$ \\
\hline $\begin{array}{l}\text { Chlorfluazuron } \\
\text { Natrilo }\end{array}$ & $50 \mathrm{~cm}^{\circ}+1,5 \mathrm{~L}$ & $43 a b c$ & $100 a$ & 48 & 79.41 & 60.31 & 85.33 & 23.42 & 59 & 22.90 & 55 & $38.66 \mathrm{abcd}$ & $74.19 \mathrm{~cd}$ \\
\hline $\begin{array}{l}\text { Chlorfluazuron + Hopa } \\
\text { oil }\end{array}$ & $100 \mathrm{~cm}^{3}+1,5$ & $54 \mathrm{bc}$ & $100 a$ & 82 & 100 & 78.12 & 100 & 17.62 & 99 & 23.51 & 82 & $50.31 \mathrm{abc}$ & $95.25 \mathrm{ab}$ \\
\hline $\begin{array}{l}\text { Chlorfluazuron+ Hopa } \\
\text { oil }\end{array}$ & $50 \mathrm{~cm}^{3}+1,5 \mathrm{~L}$ & $36 \mathrm{c}$ & $100 a$ & 78 & 96.42 & 73.44 & 88.11 & 9.41 & 75 & 7.62 & 38 & $42.12 \mathrm{~cd}$ & \begin{tabular}{|l}
$74.38 \mathrm{bcd}$ \\
\end{tabular} \\
\hline $\begin{array}{l}\text { Chlorfluazuron } \\
\text { Mesrona oil }\end{array}$ & $100 \mathrm{~cm}^{\circ}+1,5$ & $39 \mathrm{c}$ & $100 a$ & 95 & 100 & 64.52 & 95.62 & 25.93 & 76 & 28.61 & 68 & $53.52 \mathrm{abc}$ & $84.91 \mathrm{ab}$ \\
\hline $\begin{array}{l}\text { Chlorfluazuron+ } \\
\text { Mesrona oil }\end{array}$ & $50 \mathrm{~cm}^{3}+1,5 \mathrm{~L}$ & $38 a b$ & $100 a$ & 87 & 100 & 49.92 & 95.73 & 7.14 & 78 & 4.42 & 58 & $37.10 \mathrm{~cd}$ & $82.93 \mathrm{bc}$ \\
\hline Chlorfluazuron + Kz oil & $100 \mathrm{~cm}^{3}+1,5$ & $42 a b c$ & $100 a$ & 79 & 100 & 74.91 & 99.41 & 15.60 & 51 & 19.12 & 70 & $47.16 a b$ & $80.10 \mathrm{bcd}$ \\
\hline Chlorfluazuron+ Kz oil & $50 \mathrm{~cm}^{3}+1,5 \mathrm{~L}$ & $39 \mathrm{bc}$ & $100 a$ & 49 & 79.51 & 75.72 & 77.2 & 10.72 & 55 & 6.17 & 50 & $35.40 \mathrm{~cd}$ & $65.43 d$ \\
\hline $\begin{array}{l}\text { Chlorfluazuron } \\
\text { cotton seed oil }\end{array}$ & $100 \mathrm{~cm}^{3}+1,5$ & $49 a b c$ & $100 a$ & 82 & 100 & 58.61 & 97.42 & 19.61 & 94 & 16.71 & 69 & $44.23 a b$ & $92.61 \mathrm{ab}$ \\
\hline $\begin{array}{l}\text { Chlorfluazuron+ cotton } \\
\text { seed oil }\end{array}$ & $50 \mathrm{~cm}^{3}+1,5 \mathrm{~L}$ & $40 \mathrm{bc}$ & $100 a$ & 51 & 87.2 & 44.32 & 77.91 & 7.2 & 84 & 9.19 & 80 & $27.93 d$ & $82.28 \mathrm{~cd}$ \\
\hline
\end{tabular}

Mean followed by the same letter in each column are not significantly at $5 \%$ level 
Table (4) : The initial and residual activity of quarter ,half and recommended dose of Chlorfluazuron and their binary mixtures with oils against $4^{\text {th }}$ instar larvae of cotton leafworm S. littoralis

\begin{tabular}{|c|c|c|c|c|c|c|c|c|c|c|c|c|c|}
\hline \multirow[b]{3}{*}{ Treatments } & \multirow[b]{3}{*}{ Rate / fed } & \multicolumn{10}{|c|}{ Corrected $\%$ mortality at indicated time intervales } & \multirow{2}{*}{\multicolumn{2}{|c|}{$\begin{array}{c}\text { \% effectiveness(3- } \\
\text { 12days) }\end{array}$}} \\
\hline & & \multicolumn{2}{|c|}{0 day } & \multicolumn{2}{|c|}{3 day } & \multicolumn{2}{|c|}{6 day } & \multicolumn{2}{|c|}{9 day } & \multicolumn{2}{|c|}{12 day } & & \\
\hline & & 2day & 5day & 2day & 5day & 2day & 5day & 2day & 5day & 2day & 5day & $\begin{array}{c}\text { Initial } \\
\text { activity } \\
\text { 2day }\end{array}$ & $\begin{array}{c}\text { Residual } \\
\text { activity } \\
\text { 5day }\end{array}$ \\
\hline Chlorfluazuron & $400 \mathrm{~cm}^{3}$ & $86 a b$ & $100^{\mathrm{a}}$ & 77.18 & 100 & 95.68 & 100 & 68 & 97.78 & 29.92 & 90.48 & $67.85 a$ & $97.07 a$ \\
\hline Chlorfluazuron & $200 \mathrm{~cm}^{3}$ & $56 f$ & $100^{\mathrm{a}}$ & 66.67 & 100 & 91.35 & 100 & 38 & 95.57 & 22.17 & 67.19 & $54.55 \mathrm{abc}$ & $92.94 a$ \\
\hline Chlorfluazuron & $100 \mathrm{~cm}^{3}$ & 60ef & $100^{\mathrm{a}}$ & 66.67 & 100 & 89.19 & 100 & 32 & 93.33 & 0.00 & 28.57 & 46.97abcd & $80.48 a$ \\
\hline $\begin{array}{l}\text { Chlorfluazuron } \\
\text { Natrilo } \\
\end{array}$ & $+200 \mathrm{~cm}^{3}+1,5 \mathrm{~L}$ & $88 \mathrm{a}$ & $100^{\mathrm{a}}$ & 62.22 & 100 & 82.70 & 100 & 36 & 95.56 & 37.50 & 83.33 & $54.61 \mathrm{ab}$ & $94.72 a$ \\
\hline $\begin{array}{l}\text { Chlorfluazuron } \\
\text { Natrilo } \\
\end{array}$ & $+100 \mathrm{~cm}^{3}+1,5 \mathrm{~L}$ & 68cdef & $100^{a}$ & 55.56 & 100 & 80.54 & 100 & 24 & 86.67 & 14.58 & 47.14 & 43.67bcd & 82.93ab \\
\hline $\begin{array}{l}\text { Chlorfluazuron } \\
\text { Hopa oil }\end{array}$ & +200 & $84 a b c$ & $100^{a}$ & 77.87 & 100 & 82.70 & 100 & 36 & 95.57 & 29.17 & 57.14 & ab 56.44 & $88.18 a b$ \\
\hline $\begin{array}{l}\text { Chlorfluazuron+ } \\
\text { Hopa oil }\end{array}$ & $100 \mathrm{~cm}^{3}+1,5 \mathrm{~L}$ & $80 a b c d$ & $100^{\mathrm{a}}$ & 75.56 & 100 & 63.24 & 100 & 10 & 86.67 & 5.50 & 88.10 & $38.58 \mathrm{bcd}$ & $92.85 a$ \\
\hline $\begin{array}{l}\text { Chlorfluazuron } \\
\text { Mesrona oil }\end{array}$ & $+200 \mathrm{~cm}^{3}+1,5 \mathrm{~L}$ & 78abcd & $100^{\mathrm{a}}$ & 84.44 & 100 & 74.04 & 100 & 44 & 88.89 & 12.50 & 59.52 & abc53.75 & 87.10ab \\
\hline $\begin{array}{l}\text { Chlorfluazuron+ } \\
\text { Mesrona oil }\end{array}$ & $100 \mathrm{~cm}^{3}+1,5 \mathrm{~L}$ & 72bcde & $100^{a}$ & 73.33 & 100 & 63.24 & 100 & 30 & 80.00 & 4.17 & 80.95 & $42.69 a b c$ & $90.24 a b$ \\
\hline $\begin{array}{l}\text { Chlorfluazuron } \\
\text { Kz oil }\end{array}$ & $+200 \mathrm{~cm}^{3}+1,5 \mathrm{~L}$ & 74abcd & $100^{a}$ & 75.56 & 100 & 50.27 & 100 & 36 & 91.11 & 25.0 & 90.48 & abcd46.71 & $95.40 \mathrm{a}$ \\
\hline $\begin{array}{l}\text { Chlorfluazuron+ } \\
\text { Kz oil }\end{array}$ & $100 \mathrm{~cm}^{3}+1,5 \mathrm{~L}$ & $30 \mathrm{~g}$ & $100^{\mathrm{a}}$ & 55.56 & 100 & 48.27 & 100 & 22 & 80.00 & 12.0 & 90.48 & $34.46 \mathrm{~cd}$ & 92.62ab \\
\hline $\begin{array}{l}\text { Chlorfluazuron } \\
\text { cotton seed oil }\end{array}$ & $+200 \mathrm{~cm}^{3}+1,5 \mathrm{~L}$ & 62def & $100^{a}$ & 62.22 & 100 & 41.62 & 97.04 & 36 & 91.11 & 16.67 & 37.81 & $39.13 b c d$ & $90.49 a b$ \\
\hline $\begin{array}{l}\text { Chlorfluazuron+ } \\
\text { cotton seed oil }\end{array}$ & $100 \mathrm{~cm}^{3}+1,5 \mathrm{~L}$ & $34 g$ & 100 & 48.48 & 100 & 35.14 & 100 & 22 & 68.89 & 16.67 & 57.14 & d 30.68 & $81.51 \mathrm{ab}$ \\
\hline
\end{tabular}

cotton seed oil

Mean followed by the same letter in each column are not significantly at $5 \%$ level 
Table (5) : The initial and residual activity of quarter, half and recommended dose of Flufenuxuron and their binary mixtures with oils against $4^{\text {th }}$ instar larvae of cotton leafworm S. littorali

\begin{tabular}{|c|c|c|c|c|c|c|c|c|c|c|c|c|c|}
\hline \multirow[b]{3}{*}{ Treatments } & \multirow[b]{3}{*}{ Rate / fed } & \multicolumn{10}{|c|}{ Corrected $\%$ mortality at indicated time intervales } & \multirow{2}{*}{\multicolumn{2}{|c|}{$\%$ effectiveness }} \\
\hline & & \multicolumn{2}{|c|}{0 day } & \multicolumn{2}{|c|}{3 day } & \multicolumn{2}{|c|}{6 day } & \multicolumn{2}{|c|}{9 day } & \multicolumn{2}{|c|}{12 day } & & \\
\hline & & 2day & 5day & 2day & 5day & 2day & 5day & 2day & 5day & 2day & 5day & $\begin{array}{c}\text { Initial } \\
\text { activity } \\
\text { 2day }\end{array}$ & $\begin{array}{c}\text { Residual } \\
\text { activity } \\
5 \text { day }\end{array}$ \\
\hline Flufenuxuron & $200 \mathrm{~cm}^{3}$ & $58 \mathrm{a}$ & 100 & 70 & 100 & 84.78 & 100 & 22.92 & 68 & 21.28 & 65 & $49.75 a b c$ & $83.25 \mathrm{bc}$ \\
\hline Flufenuxuron & $100 \mathrm{~cm}^{3}$ & $54 a b$ & 100 & 68 & 97.22 & 78.26 & 90.91 & 20.83 & 60 & 17.02 & 58 & 46.03abcd & $71.53 \mathrm{bcd}$ \\
\hline Flufenuxuron & $50 \mathrm{~cm}^{3}$ & $50 \mathrm{abc}$ & 100 & 58 & 88.84 & 78.26 & 87.88 & 16.67 & 56 & 4.27 & 50 & 39.3abcd & $70.96 \mathrm{~cd}$ \\
\hline Chlorfluazuron + Natrilo & $100 \mathrm{~cm}^{3}+1,5 \mathrm{~L}$ & $58 a$ & 100 & 66 & 100 & 86.96 & 91.67 & 37.50 & 80 & 40.43 & 70 & $57.72 a$ & $85.42 a b c$ \\
\hline Chlorfluazuron + Natrilo & $50 \mathrm{~cm}^{3}+1,5 \mathrm{~L}$ & $40 \mathrm{abc}$ & 100 & 44 & 96.97 & 56.52 & 83.33 & 20.83 & 56 & 23.40 & 54 & $a b c d 36.19$ & $72.58 \mathrm{~cd}$ \\
\hline Chlorfluazuron + Hopa oil & $100 \mathrm{~cm}^{3}+1,5 \mathrm{~L}$ & $50 \mathrm{abc}$ & 100 & 78 & 100 & 76.09 & 100 & 14.58 & 96 & 25.53 & 78 & abc51.40 & $93.5 \mathrm{a}$ \\
\hline Chlorfluazuron+ Hopa oil & $50 \mathrm{~cm}^{3}+1,5 \mathrm{~L}$ & $34 c$ & 100 & 74 & 93.94 & 71.74 & 86.11 & 6.25 & 72 & 6.38 & 34 & $34.70 \mathrm{abcd}$ & $71.51 \mathrm{~cd}$ \\
\hline $\begin{array}{l}\text { Chlorfluazuron + Mesrona } \\
\text { oil }\end{array}$ & $100 \mathrm{~cm}^{3}+1,5 \mathrm{~L}$ & $34 c$ & 100 & 92 & 100 & 60.90 & 93.94 & 22.92 & 72 & 29.79 & 65 & $45.39 a b c$ & $82.74 b c d$ \\
\hline $\begin{array}{l}\text { Chlorfluazuron+ Mesrona } \\
\text { oil }\end{array}$ & $50 \mathrm{~cm}^{3}+1,5 \mathrm{~L}$ & $34 a b c$ & 100 & 84 & 97.22 & 47.83 & 93.94 & 4.17 & 72 & 2.79 & 54 & $\mathrm{~cd} 32.58$ & $79.29 \mathrm{bcd}$ \\
\hline Chlorfluazuron + Kz oil & $100 \mathrm{~cm}^{3}+1,5 \mathrm{~L}$ & $40 a b$ & 100 & 76 & 100 & 73.91 & 100 & 12.50 & 48 & 19.15 & 75 & ab 52.77 & $89.75 a b$ \\
\hline Chlorfluazuron+ Kz oil & $50 \mathrm{~cm}^{3}+1,5 \mathrm{~L}$ & $36 \mathrm{bc}$ & 100 & 46 & 77.78 & 71.74 & 75 & 8.33 & 52 & 4.26 & 50 & $26.03 d$ & $63.70 \mathrm{~d}$ \\
\hline $\begin{array}{l}\text { Chlorfluazuron + cotton } \\
\text { seed oil }\end{array}$ & $100 \mathrm{~cm}^{3}+1,5 \mathrm{~L}$ & $46 a b c$ & 100 & 78 & 100 & 56.52 & 96.97 & 16.67 & 92 & 14.89 & 75 & $52.77 a b$ & $90.99 \mathrm{ab}$ \\
\hline $\begin{array}{l}\text { Chlorfluazuron+ } \\
\text { seed oil }\end{array}$ & $50 \mathrm{~cm}^{3}+1,5 \mathrm{I}$ & $38 \mathrm{bc}$ & 100 & 48 & 84.55 & 41.30 & 77.78 & 4.17 & 80 & 10.54 & 57.58 & $26.03 d$ & $75.05 \mathrm{~cd}$ \\
\hline
\end{tabular}

Mean followed by the same letter in each column are not significantly at $5 \%$ I 